\title{
Pengaruh Implementasi Kebijakan Peraturan Daerah Nomor 8 Tahun 2016 Terhadap Peningkatan Kualitas Pelayanan Publik Pada Dinas Kependudukan Dan Pencatatan Sipil Kabupaten Pasaman Barat Tahun 2019-2020
}

\author{
${ }^{1}$ Ringga Febri Ananda, ${ }^{2}$ Bakaruddin Rosyidi, ${ }^{3}$ Aidinil Zetra \\ ${ }^{123}$ Magister Ilmu Politik Fakultas Ilmu Sosial Ilmu Politik, Universitas Andalas \\ e-mail :bakrandalas@gmail.com
}

\begin{abstract}
Abstrak
Penelitian ini bertujuan untuk mengetahui Pengaruh Implementasi Kebijakan Peraturan Daerah Nomor 8 Tahun 2016 Terhadap Peningkatan Kualitas Pelayanan Publik Pada Dinas Kependudukan Dan Pencatatan Sipil Kabupaten Pasaman Barat Tahun 2019-2020.Teori yang digunakan sebagai pijakan adalah Teori Implementasi Kebijakan Charles O. Jones.Metode penelitian yang digunakan adalah metode kuantitatif dengan tipe penjelasan (explanatory research).Teknik yang digunakan dalam pengumpulan data menggunakan kuesioner, sedangkan analisis data disajikan dalam bentuk tabulasi silang dan pengujian hipotesis meggunakan teknik korelasi Kendall Tau. Hasil Penelitian menunjukan bahwa Variabel X memiliki hubungan positif terhadap Variabel Y. Dengan keeratan hubungan sebesar 0,899 Organisasi, 0,903 Interpretasi, 0,989 Penerapan serta koefisien korelasi dinyatakan positif signifikan. Ini artinya jika Variabel $\mathrm{X}$ meningkat maka Variabel $\mathrm{Y}$ akan ikut meningkat. Sehingga dinyatakan bahwa Peraturan Daerah Nomor 8 Tahun 2016 memiliki hubungan sekaligus pengaruh terhadap Peningkatan Kualitas Pelayanan Publik Pada Dinas Kependudukan Dan Pencatatan Sipil Kabupaten Pasaman Barat Tahun 2019-2020.
\end{abstract}

Kata Kunci: Implementasi Kebijakan, Kualitas Pelayanan Publik

\begin{abstract}
The purpose of this researchto find out the Effect of Implementation of Regional Regulation Number 8 of 2016 on Improving the Quality of Public Services in the Population and Civil Registration Office of West Pasaman Regency in 2019-2020.The theory used as a platform is Charles O. Jones' Policy Implementation Theory. The research method used isquantitative method with explanatory research type.The technique used in data collection uses a questionnaire, while data analysis is presented in the form of cross tabulation and hypothesis testing using the Kendall Tau correlation technique. The results showed that Variable $X$ has a positive relationship with Variable Y. With a close relationship of 0.899 Organization, 0.903 Interpretation, 0.989 Applicationand the correlation coefficient was stated to be significantly positive. Thismeaning if The variable $X$ increases, the variable $Y$ will also increase. So it is stated thatRegional Regulation No. 8 of 2016 has a relationship as well as an influence on the Improvement of the Quality of Public Services in the Population and Civil Registration Office of West Pasaman Regency 2019-2020.
\end{abstract}

Keywords: Policy Implementation, Quality of Public Services 


\section{PENDAHULUAN}

Kebijakan dalam artian sederhana diartikan sebagai kajian terhadap peraturan atau program dalam rangka guna untuk mencapai tujuan tertentu.Kebijakan itu sendiri selalu dihubungkan dengan upaya penyelesaian suatu masalah.Kebijakan tidak memiliki makna dan arti apa-apa ketika kebijakan tersebut tidak diimplementasikan. Sesuai dengan pendapat Gaffar implementasi merupakan salah satu tahapan dalam proses kebijakan publik. Biasanya implementasi dilaksanakan setelah kebijakan itu dirumuskan dengan tujuan yang jelas.Implementasi ialah suatu rangkaian aktifitas dalam rangka menghantarkan kebijakan kepada masyarakat sehingga kebijakan tersebut dapat membawa hasil sebagaimana mestinya. ${ }^{1}$ Senada dengan itu Singadilaga mengatakan bahwa: "kebijakan publik merupakan keputusan yang diambil berdasarkan proses administrasi negara, akan tetapi keputusan yang menjadi kebijakan publik hanyalah keputusan-keputusan yang baik serta mengandung nilai-nilai yang mengutamakan kepentingan masyarakat (Public interest). ${ }^{2}$ Riant Nugroho mengemukakan implementasi kebijakan pada prinsipnya adalah sebuah cara agar kebijakan dapat mencapai tujuannya, tidak lebih dan tidak kurang.

Menurut Charles O. Jones dalam melaksanakan aktivitas implementasi kebijakan, terdapat tiga macam aktivitas penting yang perlu diperhatikan secara saksama, yakni:

1. Organisasi: Aktivitas organisasi (organization) dimaknai suatu upaya menetapkan dan menata kembali sumber daya, unit-unit dan metode-metode yang mengarah pada upaya mewujudkan (merealisasikan kebijakan menjadi hasil sesuai dengan apa yang menjadi tujuan dan sasaran kebijakan) seperti: kewenangan yang cukup, kejelasan prosedur, operasional standar, kesesuaian tupoksi (tugas pokok dan fungsi), beban kerja yang merata.

2. Interpretasi: Aktivitas interpretasi (interpretation) ialah aktivitas penjelasan substansi dan suatu kebijakan dalam bahasa yang lebih operasional dan mudah dipahami, sehingga substansi kebijakan dapat dilaksanakan dan diterima oleh para pelaku dan sasaran kebijakan seperti: komitmen mengenai pelayanan, kejelasan tugas, konsistensi pelaksanaan pelayanan, sosialisasi kebijakan, petunujuk pelaksanaan kebijakan.

3. Penerapan: Aktivitas penerapan (applications) merupakan aktivitas penyediaan pelayanan secara rutin dan terus menerus, pembayaran atau lainnya sesuai dengan tujuan dan sasaran kebijakan yang ada seperti: Perhatian pada prinsip kualitas, Identifikasi pelayanan, Penilaian terhadap keberhasilan pelayanan, Pengawasan terhadap capaian pelayanan, Konsistensi monev (monitoring dan evaluasi). ${ }^{3}$

Kotler menyatakan pelayanan adalah setiap kegiatan-kegiatan yang menguntungkan dalam suatu kumpulan atau kesatuan, dan menawarkan kepuasan meskipun hasilnya tidak terikat pada sebuah produk secara fisik. ${ }^{4}$ Selanjutnya Sampara berpendapat, pelayanan adalah suatu kegiatan atau urutan kegiatan yang terjadi dalam interaksi langsung antar seseorang dengan orang lain atau mesin secara fisik, dan menyediakan kepuasan pelanggan..$^{5}$ Sementara dalam Kamus Besar Bahasa Indonesia dijelaskan pelayanan sebagai hal, cara, atau hasil pekerjaan melayani. Sedangkan melayani adalah menyuguhi (orang) dengan makanan atau minuman; menyediakan keperluan orang; mengiyakan; menerima; menggunakan. ${ }^{6}$

\footnotetext{
${ }^{1}$ AfanGaffar,Politik Indonesia: Transisi Menuju Demokrasi, Pustaka Pelajar, Yogyakarta, 2009, hlm. 295.

${ }^{2}$ Dudi Singadilaga, Politik Luar Negeri Indonesia, Alumni, Bandung, 2003, hlm. 7.

${ }^{3}$ Leo Agustino, Dasar- Dasar Kebijakan Publik, Alfabeta, Bandung, 2016, hlm. 154-155.

${ }^{4}$ Sampara Lukman, Manajemen Kualitas Pelayanan, STIA LAN Press, Jakarta, 2000, hlm. 8.

${ }^{5}$ Ibid.,hlm. 6.

${ }^{6}$ Lihat https://kbbi.web.id/layan, Pengertian Pelayanan, diakses pada tanggal 10 Oktober 2019 pukul 11:55.
} 
Kemudian istilah publik berasal dari Bahasa Inggris public yang berarti umum, masyarakat, negara.Kata publik sebenarnya sudah diterima menjadi Bahasa Indonesia Baku menjadi Publik yang berarti umum, orang banyak, ramai. ${ }^{7}$ Padanan kata yang tepat digunakan adalah praja yang sebenarnya bermakna rakyat sehingga lahir istilah pamong praja yang berarti pemerintah yang melayani kepentingan seluruh rakyat.Dapat diartikan pelayanan publik adalah sebagai setiap kegiatan yang dilakukan oleh pemerintah terhadap sejumlah manusia yang memiliki setiap kegiatan yang menguntungkan dalam suatu kumpulan atau kesatuan, dan menawarkan kepuasan meskipun hasilnya tidak terikat pada suatu produk secara fisik. ${ }^{8}$

Dengan demikian, pelayanan publik adalah pemenuhan keinginan dan kebutuhan masyarakat oleh penyelenggara negara.Negara didirikan oleh publik (masyarakat) tentu saja dengan tujuan agar dapat meningkatkan kesejahteraan masyarakat.Pada hakikatnya negara dalam hal ini pemerintah (birokrat) haruslah dapat memenuhi kebutuhan masyarakat. Dimana kebutuhan ini ialah berbagai kebutuhan yang diharapkan oleh masyarakat, misalnya kebutuhan akan kesehatan, pendidikan, dan lain-lain. Perihal kebutuhan Sinambela mengungkapkan, bahwa pelayanan sebagai proses pemenuhan kebutuhan melalui aktivitas orang lain secara langsung dan merupakan konsep yang senantiasa aktual dalam berbagai aspek kelembagaan, bukan hanya pada organisasi bisnis, tetapi telah berkembang lebih luas pada tatanan organisasi pemerintah (birokrasi). ${ }^{9}$ Kembali ditegaskan pada dasarnya pemerintah (birokrat) adalah pelayan untuk masyarakat.Rasyid mengatakan bahwa pemerintah pada hakikatnya adalah pelayanan kepada masyarakat.Pemerintah tidaklah diadakan untuk melayani dirinya sendiri, tetapi untuk melayani masyarakat. ${ }^{10}$

Berbicara mengenai pelayanan publik tentu tidak terlepas dari kualitas pelayanan Gaspersz mengemukakan dimana kata kualitas memiliki banyak defenisi yang berbeda dan bervariasi mulai yang dari konvensional hingga yang lebih strategis.Defenisi konvensional dari kualitas biasanya menggambarkan karakteristik langsung dari suatu produk, seperti Kinerja (performance), keandalan (reliability), mudah dalam penggunaan (ease of use), estetika (esthetics) dan sebagainya.Dalam defenisi strategis dinyatakan bahwa kualitas adalah segala sesuatu yang mampu memenuhi keinginan atau kebutuhan pelanggan (meeting the needs of customers). ${ }^{11}$

Berdasarkan pengertian kualitas baik yang konvensional maupun yang lebih strategis disampaikan oleh Gaspersz pada dasarnya kualitas mengaju pada pengertian pokok:

1. Kualitas terdiri atas sejumlah keistimewaan produk, baik keistimewaan langsung, maupun keistimewaan atraktif yang memenuhi keinginan pelanggan dan memberikan kepuasaan atas penggunaan produk;

2. Kualitas juga terdiri atas segala sesuatu yang bebas dari kekurangan atau kerusakan. ${ }^{12}$

Dari berbagai definisi kualitas, dapat dipahami bahwa kualitas mengandung makna adanya suatu keunggulan atau mutu terhadap produk (barang dan jasa) yang dihasilkan oleh produsen (penyedia pelayanan) dalam rangka memenuhi harapan pelanggan atau masyarakat (publik).Berhubungan dengan pelayanan publik, keunggulan tersebut adalah pelayanan yang dapat memberikan rasa kepuasan kepada yang dilayani dan keunggulan tersebut perlu terus dievaluasi dan ditingkatkan agar harapan pelanggan yang bersifat dinamis itu terus dapat terpenuhi. Tjiptono juga mengungkapkan hal yang senada, dimana

\footnotetext{
${ }^{7}$ Ibid.

${ }^{8}$ Ibid.

${ }^{9}$ Lijan Poltak Sinambela, dkk.,Reformasi Pelayanan Publik, Bumi Aksara, Jakarta, 2006, hlm. 42-43.

${ }^{10}$ Al Rasyid Harun, Manajemen Pelayanan Umum, Bumi Aksara, Jakarta, 1997, hlm. 11.

${ }^{11}$ Sinambela,Op.cit.,hlm. 6.

${ }^{12}$ Ibid.
} 
kualitas pelayanan itu ialah suatu kondisi dinamis yang berpengaruh dengan produk, jasa, manusia, proses dan lingkungan yang memenuhi atau melebihi harapan. ${ }^{13}$

Maka memang tidak bisa dihindari bahwa pelayanan publik itu harus memiliki kualitas, bahkan menjadi tolak ukur kesuksesan pemerintah selaku pemberi pelayanan kepada masyarakat.Menurut Zeithaml, Parasuraman dan Berry secara umum pelayanan dapat dikatakan berkualitas apabila telah memenuhi kriteria sebagai berikut:

1. Tangibles (bukti fisik): dimensi ini merupakan gambaran dari keadaan fisik yang terlihat dari pemberi layanan seperti: adanya fasilitas gedung, fisik peralatan, tata letak dan tampilan barang, kenyamanan, pegawai, peralatan, dan perlengkapan moderen.

2. Reliability (kehandalan): dimensi ini mencakup dua hal pokok, yaitu konsistensi kerja (performance) dan kemampuan untuk dipercaya (dependability). Hal ini berarti perusahaan harus memberikan pelayanannya secara tepat sejak saat pertama (right in the firts time). Karena dengan demikian, perusahaan akan dilihat sebagai perusahaan yang menepati janji dan berkomitmen kepada publiknya seperti: kemampuan memberikan pelayanan yang dijanjikan dengan segera, akurat, dan memuaskan.

3. Responsiveness (ketanggapan): dimensi ini merupakan pelayanan yang baik harus disertai dengan tingkat keikutsertaan /keterlibatan dan daya adaptasi yang tinggi. Contohnya membantu memecahkan masalah seperti: keinginan para staf untuk membantu para pelanggan, dan memberikan pelayanan dengan tanggap.

4. Assurance (jaminan/kepastian): dimensi ini merupakan pertanggungjawaban dari sipemberi layanan seperti: pengetahuan, kemampuan, dari bahaya, resiko atau keragu-raguan.

5. Emphaty (empati): dimensi ini merupakan adanya kemampuan sipemberi layanan untuk berbagi perasaan yang dilandasi oleh rasa kepedulian kepada yang membutuhkan pelayanan seperti: kemudahan dalam melakukan hubungan, komunikasi yang baik, perhatian pribadi, dan memahami kebutuhan para pelanggan. ${ }^{14}$

Bertumpu pada apa yang dikatakan Jones di atas, maka masalah implementasi kebijakan semakin lebih jelas dan luas. Di mana implementasi merupakan proses yang memerlukan tindakan-tindakan yang sistematis dari Organisasi, Interpretasi dan Penerapan. Ketiga aktivitas ini sama halnya kita berbicara tentang aktivitas kelembagaan, dimana dalam rangka mendekatkan pelaksanaan tugas pokok dan fungsi pelayanan kepada masyarakat perlunya dikembangkan berbagai macam program inovasi dalam mewujudkan pelayanan yang berkualitas.

Dalam hal ini Disdukcapil Kabupaten Pasaman Baratsepertinya telah membuktikan upaya Implementasi Kebijakan Peraturan Daerah Nomor 8 Tahun 2016. Sebagai salah satu pertimbangannya terdapat pada Pasal 5 ayat (1) huruf b dan Pasal 6 ayat (1) huruf e yang berbunyi bahwa Disdukcapil harus memberikan pelayanan yang sifatnya sama (tidak diskriminatif) dan profesional kepada setiap penduduk atau masyarakat atas pelaporan peristiwa kependudukan dan peristiwa penting, serta melakukan pelaksanaan kegiatan pelayanan masyarakat di bidang administrasi kependudukan dan pencatatan sipil secara berkelanjutan, cepat dan mudah kepada seluruh penduduk.

Dengan pertimbangan Pasal 5 ayat (1) huruf b dan Pasal 6 ayat (1) huruf e serta kutipan dari berbagai berita dan observasi peneliti kelapangan telah banyak terjadi perubahan-perubahan, disini jelas bahwa Dinas Kependudukan Dan Pencatatan Sipil tersebut telah mengimplementasikan Kebijakan Peraturan Daerah Nomor 8 Tahun 2016 dengan meluncurkan beberapa produk pelayanan bagi masyarakat diantaranya adalah: 1) Program One Day Service, ialah Pelayanan dokumen sehari siap dengan syarat

\footnotetext{
${ }^{13}$ Tjiptono.,Loc.cit.

${ }^{14}$ Hardiansyah.,Loc.cit.
} 
lengkap dan masyarakat diminta untuk mengurus administrasi kependudukannya sendiri guna menghindari paraktik percaloan. 2) Program Aplikasi Disdukcapil Mobile (DPM), ialah Aplikasi yang berbasis Android untuk memudahkan masyarakat mengurus dokumen kependudukan melalui dunia yang disebut dengan dunia digital. Dengan program tersebut katanya Pemerintah hadir untuk memberikan kemudahan dalam urusan pelayanan yang lebih mengutamakan harapan dan kepuasan masyarakat dalam mengurus dokumen kependudukan demi untuk meningkatkan kualitas pelayanan Disdukcapil Kabupaten Pasaman Barat.

Oleh sebab itu penulisberasumsi implementasi kebijakan peraturan daerah nomor 8 tahun 2016memiliki pengaruh terhadap peningkatan kualitas pelayanan publik pada Dinas Kependudukan dan Pencatatan Sipil Kabupaten Pasaman Barat. Karena sejak disahkannya perda tersebut telah banyak terjadi perubahan-perubahan, mulai dari perbaikan dan penataan ulang pada tubuh birokrasinya sampai memperbarui segala program, kelengkapan administrasi dan alat-alat yang akan menunjang dan meningkatkan kualitas pelayanan publiknya, serta birokrasi ini juga memberikan kemudahan dalam urusan pelayanan yang mengutamakan harapan dan kepuasan masyarakatnya.

\section{METODE}

Dalam penulisan ini menggunakan pendekatan kuantitatif, dengan desain penelitian survei. ${ }^{15}$ Dengan menggunakan pendekatan kuantitatif ini, nantinya akan diperoleh data-data melalui angka-angka yang empirik sehingga memungkinkan untukmenganalisis data tersebut. Desain penelitian survei adalah penelitian yang mengambil sampel dari satu populasi dan menggunakan kuesioner sebagai alat pengumpulan data yang pokok. ${ }^{16}$ Sedangkan pengertian lain dari penelitian survei adalah penelitian yang pada umumnya digunakan untuk pengumpulan data yang luas dan banyak penelitian ini dapat dilakukan pada populasi besar maupun kecil, namun data tetap dari sampel yang diambil dari populasi tersebut. ${ }^{17}$ Oleh sebab itu penelitian ini juga mampu menjelaskan Survei Kepuasan Masyarakat (SKM) dengan proses pengumpulan data yang lebih efisien dari sampel atau sebagaian populasi (besar/kecil) namun tetap mampu menggambarkan sifat-sifat populasi dalam penelitian ini.

Tipe penelitian yang digunakan adalah tipe explanatory research.Singarimbun dan Effendi menjelaskan explanatory research yaitu penelitian yang digunakan untuk menjelaskan hubungan kausal antara variabel-variabel melalui pengujian hipotesis yang dirumuskan atau sering kali disebut sebagai tipe penelitian penjelas. ${ }^{18}$ Karena itulah pada penelitian ini peneliti ingin menjelaskan hubungan kausal (hubungan yang bersifat sebab akibat). ${ }^{19}$ Kemudian Jenis penelitian ini, berdasarkan dimensi waktu adalah penelitian Cross-Sectional yaitu penelitian ini hanya digunakan dalam waktu tertentu, dan tidak dilakukan penelitian lain diwaktu yang berbeda untuk diperbandingkan. ${ }^{20}$

\footnotetext{
${ }^{15}$ Masri Singarimbun dan Sofyan Efendi, Metode Penelitian Survei, LP3S, Jakarta, 1995,hlm. 3.

${ }^{16}$ Singarimbun., Loc.cit.

${ }^{17}$ Muhammad Ali, Metodologi dan Aplikasi Riset Pendidikan, Bumi Aksara, Jakarta, 2014, hlm. 23.

${ }^{18}$ Singarimbun., Loc.cit.

${ }^{19}$ Sugiyono, Metode Penelitian Kuantitatif Kualitatif Dan R\&D, CV Alfabeta, Bandung, 2011, hlm. 37.

${ }^{20}$ Bambang Prasetyo dan Lina Miftahul Jannah, Metode Penelitian Kuantitatif : Teori dan Aplikasi, PT Raja Grafindo Persada, Jakarta, 2005, hlm. 45.
} 


\section{HASIL DANPEMBAHASAN}

Pelayanan publik adalah segala bentuk jasa pelayanan, baik dalam bentuk barang publik maupun jasa publik yang pada prinsipnya menjadi tanggung jawab dan dilaksanakan oleh instansi pemerintah di pusat maupun di daerah, dalam rangka upaya pemenuhan kebutuhan masyarakat maupun dalam rangka pelaksanaan ketentuan peraturan perundang-undangan Ratminto. ${ }^{21}$ Mengenai pelayanan publik dalam sebuah negara pasti tidak terlepas dari istilah birokrasi.Peter Michael Blau mengungkapkan Birokrasi sebagai tipe dari suatu organisasi yang dimaksudkan untuk mencapai tugas-tugas administratif yang besar dengan cara mengkoordinir secara sistematis (teratur). ${ }^{22}$ Birokrasi juga bisa dikatakan sebagai penghubung antara masayarakat dan pemerintah, sehingga menjadikan birokrasi suatu organisasi yang digunakan pemerintah untuk pelaksana dalam bidang pelayanan publik (publik service), dan inilah yang selalu membuat adanya tuntutan disetiap unsur dalam lembaga tersebut untuk selalu memberikan pelayanan yang prima kepada masyarakat.Pelayanan prima mengandung pengertian yaitu salah satu usaha yang dilakukan pemerintah untuk melayani masyarakat dengan sebaik-baiknya, sehingga dapat memberikan kepuasan kepada masyarakat dan memenuhi kebutuhan serta keinginan masyarakat.

Pemerintah dengan sistem administrasinya itu harus mengabdi kepada rakyatnya, hal itu dapat dilihat sampai sejauh mana pelayanan yang diberikan apakah itu baik atau tidak. Pelayanan yang baik memiliki wujud tata administrasi yang baik dan amanah bisa diamati dari cara memberikan pelayanan kepada publik. Pengertian baik dan amanah ini adalah sesuai dengan keinginan masyarakat pemangku kepentingan pelayananan bukan semata-mata keinginan penguasa pemerintah. ${ }^{23}$ Sesuai dengan yang dikemukakan oleh Vincent Gaspersz bahwa pelayanan yang baik dan berkualitas terdiri atas segala sesuatu yang bebas dari kekurangan ataupun kerusakan, menurutnya dimensi pelayanan tersebut penting untuk diperhatikan dalam meningkatkan kualitas pelayanan publik. ${ }^{24}$

Tjiptono menyampaikan Kualitas merupakan suatu kondisi dinamis yang berhubungan dengan produk, jasa, manusia, proses dan lingkungan yang memenuhi atau melebihi harapan. ${ }^{25}$ Dari pengertian ini, kualitas mengandung unsur-unsur yang meliputi usaha memenuhi atau melebihi harapan pelanggan.Dengan demikian Saefullah menegaskan penilaian tentang kualitas pelayanan bukan berdasarkan pengakuan dari yang memberi pelayanan, tetapi diberikan oleh langganan atau pihak yang menerima pelayanan. ${ }^{26}$ Dalam hubungan ini, untuk dapat memberikan pelayanan yang berkualitas, maka organisasi publik atau pemerintah harus mengetahui dan memahami segala tuntutan, keinginan, dan harapan masyarakat, melalui apa yang dinamakan listening to thevoice of the customerOsborne dan Gaebler. ${ }^{27}$ Zeithaml, Parasuraman dan Berry secara umum kualitas pelayanan harus memiliki lima dimensi, kelima dimensi itu berupa; Tangibles (bukti fisik), Reliability (kehandalan), Responsiveness (ketanggapan), Assurance (jaminan/kepastian), Emphaty (empati). ${ }^{28} \mathrm{Jika}$ lima dimensi ini terpenuhi maka dapat dikatakan pelayanan itu berkualitas.

\footnotetext{
${ }^{21}$ Atik Septi Winarsih Ratminto, Manajemen Pelayanan, Pustaka Belajar, Yogyakarta, 2007, hlm. 5.

${ }^{22}$ Hisam., Loc.cit.

${ }^{23}$ Miftah Thoha, Birokrasi Pemerintah dan Kekuasaan di Indonesia, Thafa Media, Yogyakarta, 2003, hlm. 81.

${ }^{24}$ Ibid.

${ }^{25}$ Fandy., Loc.cit.

${ }^{26}$ Saefullah, Konsep dan Metode Pelayanan Umum yang Baik, Dalam Jurnal Ilmu Sosial dan Ilmu Politik, Sumedang, 1999, Fisip UNPAD, hlm. 9.

${ }^{27}$ David Osborne and Ted Gaebler, Reinventing Government : How The Entrepreneur Spirit is Transforming The Public Service, terjemahan : Mewirausahakan Birokrasi Mentransformasikan Semangat Wirausaha ke Dalam Sektor Publik, Alih Bahasa Abdul Rosyid dan Ramelan, Pustaka Binaman Pressindo, Jakarta, 1992, hlm. 177.

${ }^{28}$ Hardiansyah.,Loc.cit.
} 
Seperti yang dikatakan sebelumnya pelayanan publik pada dasarnya adalah tanggung jawab pemerintah pusat maupun pemerintah daerah.Melalui konsep otonomi daerah pemerintah daerah memiliki kewenangan yang besar untuk menetapkan kebijakan dalam menangani pelayanan publik sesuai dengan situasi dan kondisi daerahnya masing-masing. Untuk mencapai pelayanan publik yang berkualitas khususnya pelayanan publik ditingkat daerah tidaklah semudah yang dibayangkan, namun pencapaian itu harus di barengi dengan pembuatan kebijakan yang sesuai, sehingga pada akhirnya kebijakan tersebut berhasil diimplementasikan.

Kebijakan dalam artian sederhana merupakan kajian terhadap peraturan atau program dalam rangka mencapai tujuan tertentu.Kebijakan itu sendiri selalu dihubungkan dengan upaya penyelesaian masalah.Sebuah kebijakan tidak memiliki makna apa-apa ketika kebijakan tersebut tidak diimplementasikan. Sesuai dengan pendapat Gaffar implementasi merupakan salah satu tahap dalam proses kebijakan publik. Biasanya implementasi dilaksanakan setelah sebuah kebijakan dirumuskan dengan tujuan yang jelas.Implementasi adalah suatu rangkaian aktifitas dalam rangka menghantarkan kebijakan kepada masyarakat sehingga kebijakan tersebut dapat membawa hasil sebagaimana yang diharapkan. ${ }^{29}$ Ini sesuai dengan pandangan Van Meter dan van Horn bahwa tugas implementasi adalah membangun jaringan yang memungkinkan tujuan kebijakan publik direalisasikan melalui aktivitas instansi pemerintah yang melibatkan berbagai pihak yang berkepentingan. ${ }^{30}$ Senada dengan itu Singadilaga mengatakan bahwa: "kebijakan publik adalah keputusan yang diambil dalam proses administrasi negara, akan tetapi keputusan yang menjadi kebijakan publik hanyalah keputusan-keputusan yang baik dan mengandung nilai-nilai demi kepentingan masyarakat (Public interest). ${ }^{31}$ Menurut Charles O. Jones menyebutkan dalam melaksanakan aktivitas implementasi kebijakan, terdapat tiga macam aktivitas penting yang perlu diperhatikan secara saksama, yakni: Organisasi, Interpretasi, Penerapan. ${ }^{32}$

Dinas Kependudukan Dan Pencatatan Sipil Kabupaten Pasaman Barat merupakan salah satu organisasi birokrasi pemerintah di tingkat daerah yang memberikan pelayanan publik administratif pengurusan dokumen-dokumen kependudukan dan pencatatan sipil.Sesuai dengan realitas di lapangan serta dari berbagai sumber Disdukcapil Kabupaten Pasaman Barat sepertinya telah menemukan dan membuat kebijakan yang sesuai dalam penanganan masalah peningkatan kualitas pelayanan publik. Kebijakannya adalah Peraturan Daerah Nomor 8 Tahun 2016 tentang Penyelenggaraan Administrasi Kependudukan, dan sampai sekarang unit pelayanan ini telah membuktikan upaya implementasi kebijakan tersebut. Seperti yang telah disebutkan pada bab sebelumnya, dimana dari kutipan berita dan dengan pertimbangan Pasal 5 ayat (1) huruf b dan Pasal 6 ayat (1) huruf e jelas bahwa Dinas Kependudukan Dan Pencatatan Sipil tersebut telah mengimplementasikan Kebijakan Peraturan Daerah Nomor 8 Tahun 2016 dengan meluncurkan beberapa produk pelayanan bagi masyarakat diantaranya adalah: 1) ProgramOne Day Service, ialah Pelayanan dokumen sehari siap dengan syarat lengkap dan masyarakat diminta untuk mengurus administrasi kependudukannya sendiri guna menghindari paraktik percaloan. 2) Program Aplikasi Disdukcapil Mobile (DPM), ialah Aplikasi berbasis Android untuk memudahkan masyarakat mengurus dokumen kependudukan melalui dunia digital. Dengan program tersebut katanya Pemerintah hadir untuk memberikan kemudahan dalam urusan pelayanan yang lebih mengutamakan harapan dan kepuasan masyarakat dalam mengurus dokumen kependudukan demi untuk meningkatkan kualitas pelayanan Disdukcapil Kabupaten Pasaman Barat.

\footnotetext{
${ }^{29}$ AfanGaffar., Loc. cit.

${ }^{30}$ S. Merilee Grindle, Politics and Policy Implementation In The Third World, Princeton University Press, New Jersey, 1980, hlm. 105.

${ }^{31}$ Dudi Singadilaga., Loc. cit.

${ }^{32}$ Leo Agustino., Loc. cit.
} 
Berdasarkan paparan di atas peneliti teringat sebuah kalimat perihal implementasi kebijakan, dimana implementasi kebijakan merupakan aspek yang sangat penting dari keseluruhan proses kebijakan, kalimat itu tegas dinyatakan oleh Udoji yaitu "Pelaksanaan kebijakan adalah suatu yang penting, bahkan jauh lebih penting dari pembuatan kebijakan, kebijakan-kebijakan akan sekedar berupa impian atau rencana bagus yang tersimpan rapi dalam arsip kalau tidak diimplementasikan." 33 Dari pernyataan Udoji Disdukcapil Kabupaten Pasaman Barat jelas tidak menyimpan dan tidak menjadikan kebijakan tersebut sekedar impian belaka, namun kebijakan itu justru diimplementasikan dengan sebaik-baiknya melalui tiga aktivitas penting dalam implementasi kebijakan yang dikatakan oleh Charles O. Jones, sehingga peneliti menduga bahwa tiga aktivitas itu terdapat hubungan sekaligus pengaruh terhadap Peningkatan Kualitas Pelayanan Publik Pada Dinas Kependudukan Dan Pencatatan Sipil Kebupaten Pasaman Barat Tahun 2019-2020. Berikut daftarnya:

1. Organisasi: Aktivitas organisasi (organization) merupakan suatu upaya menetapkan dan menata kembali sumber daya, unit-unit dan metode-metode yang mengarah pada upaya mewujudkan (merealisasikan kebijakan menjadi hasil sesuai dengan apa yang menjadi tujuan dan sasaran kebijakan) seperti: kewenangan yang cukup, kejelasan prosedur, operasional standar, kesesuaian tupoksi (tugas pokok dan fungsi), beban kerja yang merata.

2. Interpretasi: Aktivitas interpretasi (interpretation) merupakan aktivitas penjelasan substansi dan suatu kebijakan dalam bahasa yang lebih operasional dan mudah dipahami, sehingga substansi kebijakan dapat dilaksanakan dan diterima oleh para pelaku dan sasaran kebijakan seperti:

3. komitmen mengenai pelayanan, kejelasan tugas, konsistensi pelaksanaan pelayanan, sosialisasi kebijakan, petunujuk pelaksanaan kebijakan.

4. Penerapan: Aktivitas penerapan (applications) merupakan aktivitas penyediaan pelayanan secara rutin, pembayaran atau lainnya sesuai dengan tujuan dan sasaran kebijakan yang ada seperti: Perhatian pada prinsip kualitas, Identifikasi pelayanan, Penilaian terhadap keberhasilan pelayanan, Pengawasan terhadap capaian pelayanan, Konsistensi monev (monitoring dan evaluasi). $^{34}$

Penelitian yang sudah dilaksanakan ini merupakan salah satu bentuk ketertarikan penulis untuk meneliti Pengaruh Implementasi Kebijakan Peraturan Daerah Nomor 8 Tahun 2016 Terhadap Peningkatan Kualitas Pelayanan Publik Pada Dinas Kependudukan Dan Pencatatan Sipil Kabupaten Pasaman Barat Tahun 2019-2020.Berdasarkan temuan data penelitian di lapangan dapat digambarkan yang menjadi responden dalam penelitian ini adalah masyarakat Kabupaten Pasaman Barat yang ditemui telah selesai menerima pelayanan atau pernah mendapatkan pelayanan pada Dinas Kependudukan Dan Pencatatan Sipil Kabupaten Pasaman Barat tahun 2019-2020.Rata-rata usia responden yang mendatangi instansi tersebut tergolong pada rentang usia kisaran umur 18-47 tahun dan diatas 50 tahun hanya beberapa responden saja, selanjutnya responden dengan jenis kelamin laki-laki lebih banyak dari pada responden jenis kelamin perempuan, dengan banding 90:62 responden, dan tingkat pendidikan responden lebih banyak tamatan SLTA yaitu sebanyak 93 responden, sedangkan berdasarkan pekerjaan lebih banyak responden bekerja sebagai wiraswasta yaitu sebanyak 38 responden, dan selebihnya terbagi kebeberapa jenis pekerjaan yang lain.

Penelitian ini menggunakan empat Variabel yaitu tiga Variabel bebas atau independent (Variabel $\mathrm{X}$ ) yang terdiri dari Organisasi (X1), Interpretasi (X2), Penerapan (X3), dansatuVariabel terikat atau dependent (Variabel Y) yakni Peningkatan Kualitas Pelayanan Publik Pada Dinas Kependudukan Dan Pencatatan Sipil Kabupaten Pasaman Barat Tahun 2019-2020 (Y). Antara Variabel bebas atau

\footnotetext{
${ }^{33}$ Leo Agustino,Op.cit.,hlm. 140.

${ }^{34}$ Leo Agustino, Op.cit.,hlm. 154-155.
} 
independent (Variabel X) di atas ditemukan hasil dalam penelitian ini memiliki hubungan positif terhadap Variabel terikat atau dependent (Variabel Y).Hal tersebut dapat diketahui dari hasil analisis tabulasi silang antara Variabel. Dari analisis data di atas yang dilakukan pengujian hipotesis penelitian antara tiga Variabel bebas atau independent (Variabel X) dengan satu Variabel terikat atau dependent (Variabel Y) memperoleh hasil bahwa tiga (Variabel X) terdapat hubungan positif terhadap (Variable Y).Berikut Model hubungan (Variabel X) terhadap (Variabel Y) setelah didapatkan nilai keeratan hubungan melalui pengujian dengan menggunakan rumus Kendall Tau.Lihat bagan berikut:

Model Keeratan Hubungan Antara Variabel X Terhadap Variabel Y

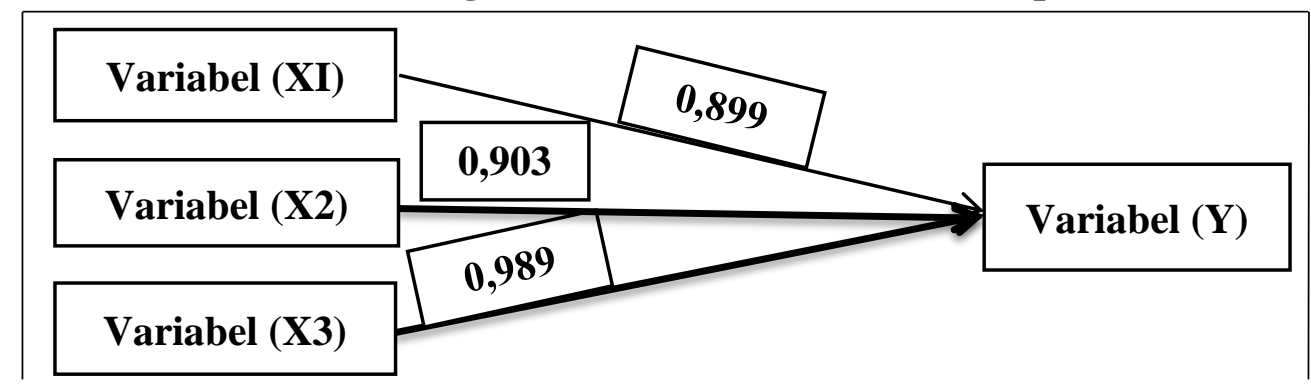

Sumber: Diolah Dari Data Primer Disdukcapil Kabupaten Pasaman Barat (2019-2020)

Masing-masing (Variabel X) memiliki keeratan hubungan terhadap (Variabel Y) sebesar 0,899 (X1), 0,903 (X2), 0,989 (X3). Setelah ditemukan nilai keeratan hubungan masing-masing Variabel diatas selanjutnya diuji pula signifikansi korelasinya (apakah koefisien korelasi itu dapat digeneralisasikan atau tidak) yaitu dengan menggunakan rumus $\mathrm{z}$, seperti yang sudah dijelaskan sebelumnya ditemukan nilai/harga z hitung dari masing-masing variabel yaitu 12,01 (X1), 12,07 (X2), 13,22 (X3).

Harga $\mathrm{z}$ hitung di atas selanjutnya akan dibandingkan dengan $\mathrm{z}$ tabel. Berdasarkan harga tersebut, signifikan atau tidaknya dapat digunakan bahwa, bila $\mathrm{z}$ hitung lebih besar $>$ dari z tabel maka koefisien korelasi yang ditemukan signifikan. Ternyata dalam penelitian ini, $\mathrm{z}$ hitung masing-masing Variabel lebih besar dari z tabel 1,96, maka H0 ditolak dan Ha diterima serta koefisien korelasi signifikan. Sehingga dapat dikatakan korelasi antara Variabel (X1), (X2), (X3) terhadap Peningkatan Kualitas Pelayanan Publik Pada Dinas Kependudukan Dan Pencatatan Sipil Kabupaten Pasaman Barat Tahun 2019-2020 (Y) adalah Positifsignifikan. ${ }^{35}$

\section{KESIMPULAN}

Jelas bahwa tiga aktivitas penting dalam implementasi kebijakan, yakni: Organisasi, Interpretasi, Penerapan. ${ }^{36}$ Secara parsial ${ }^{37}$ masing-masing aktivitas tersebut memiliki hubungan positif terhadap Peningkatan Kualitas Pelayanan Publik Pada Dinas Kependudukan Dan Pencatatan Sipil Kabupaten Pasaman Barat Tahun 2019-2020.Organisasi secara parsial memiliki pengaruh yang cukup kuat, Interpretasi secara parsial memiliki pengaruh yang kuat, dan Penerapan secara parsial memiliki pengaruh yang kuat pula. ${ }^{38}$ Sedangkan pengujian secara $\operatorname{simultan}^{39}$ menunjukkan bahwa Pengaruh Impelementasi

\footnotetext{
${ }^{35}$ Ibid. Korelasi positif signifikan berartimisal jika skor subjek pada variabel A tinggi, maka skor subjek pada variabel B juga ikut tinggi.

${ }^{36}$ Leo Agustino., Loc.cit.

${ }^{37}$ Parsial adalah bagian dari keseluruhan

${ }^{38}$ Lihat Tabel Data Primer Peneliti Tentang Keeratan Hubungan Masing-Masing Variabel X Terhadap Variabel Y Didapat Dari Hasil Pengujian Hipoteis Dengan Teknik Korelasi Kendal Tau, hlm. 101.
} 
Kebijakan Peraturan Daerah Nomor 8 tahun 2016 berpengaruh positif signifikan terhadap Peningkatan Kualitas Pelayanan Publik Pada Dinas Kependudukan Dan Pencatatan Sipil Kabupaten Pasaman Barat Tahun 2019-2020. Ini artinya jika Semakin Sangat Baik Organisasi (X1), Interpretasi (X2), Penerapan (X3) maka akan semakin Sangat Baik Pula Peningkatan Kualitas Pelayanan Publik Pada Dinas Kependudukan Dan Pencatatan Sipil Kabupaten Pasaman Barat Tahun 2019-2020 (Y).

Karena sejak diimplementasikannya kebijakan Peraturan Daerah Nomor 8 Tahun 2016 telah banyak terjadi perubahan serta penataan ulang pada tubuh birokrasinya.Hal itu terlihat dari hasil kuesioner dengan Output SPSS tabulasi silang dimana sebagian besar responden menyatakan variabel X Baik dan bahkan Sangat Baik terhadap variabel Y. Seperti yang sudah dijelasakan sebelumnya inilah yang membuat Variabel Y mengalami peningkatatan, sederhananya jika Variabel X meningkat maka dapat dipastikan Variabel Y akan ikut meningkat dan kualitas pelayanan publik akan berkualitas. Maka disinilah peneliti mengatakan bahwa Peraturan Daerah Nomor 8 Tahun 2016 memiliki hubungan sekaligus pengaruh terhadap Peningkatan Kualitas Pelayanan Publik Pada Dinas Kependudukan Dan Pencatatan Sipil Kabupaten Pasaman Barat Tahun 2019-2020.Sehingga pelayanan publik pada Dinas Kependudukan Dan Pencatatan Sipil Kabupaten Pasaman Barat Tahun 2019-2020 dinyatakan berkualitas. Tentu dalam hal ini secara langsung masyarakat Kabupaten Pasaman Barat telah merasakan dampak baik atas kualitas tersebut salah satunya adalah masayarakat tidak lagi merasakan adanya kesulitan-kesulitan untuk proses administrasi pelayanan.

\section{SARAN}

Berdasarkan paparan di atas maka saran yang sekiranya bisa memberikan masukan untuk kedepannya adalah:

1. Hasil penelitian ini diharapkan dapat menambah wawasan pengetahuan. Khususnya yang berminat untuk mengetahui lebih jauh tentang pengaruh implementasi kebijakan terhadap peningkatan kualitas pelayanan yang ada di Kabupaten Pasaman Barat (melakukan penelitian) maka perlu

2. modifikasi variabel-variabel independen baik menambah variabel atau menambah time series datanya. Sehingga akan lebih objektif dan bervariasi dalam melakukan penelitian.

3. Dengan diimplementasikan kebijakan peraturan daerah nomor 8 tahun 2016 tersebut, hendaknya memberikan dampak berkelanjutan kepada Pemerintah Kabupaten Pasaman Barat dalam hal peningkatan kualitas pelayanan publik dengan cara membuat kebijakan lain yang sesuai dengan masalah yang dihadapi lalu kemudian diimplementasikan, dievaluasi dan ditingkatkan agar harapan masyarakat terus dapat terpenuhi.

4. Penelitian seperti ini hendaknya tidak hanya dilakukan pada Disdukcapil Kabupaten Pasaman Barat saja, namun bisa juga dilakukan pada Disdukcapil di Kabupaten lain, agar nantinya ada generalisasi terhadap teori impelementasi kebijakan dan teori kualitas pelayanan publik. Sehingga bisa dijadikan perbandingan antara keduanya.

5. Instansi atau unit peneyedia pelayanan publik ini harus bisa memberikan pelayanan yang berkualitas, sehingga dapat memenuhi atau melebihi harapan dan keinginan masyarakatnya. Hal ini bisa terwujud dengan cara peningkatan SDM apartur/petugas seperti melakukan pelatihanpelatihan dibidang peningkatan dan perbaikan kualitas pelayanan publik.

Penelitian ini dapat dijadikan sebagai bahan evaluasi dan perbaikan dalam hal pengaruh implementasi kebijakan terhadap peningkatan kualitas pelayanan publik dimasa yang akan datang, khususnya pada Disdukcapil Kabupaten Pasaman Barat.

\footnotetext{
${ }^{39}$ Simultan adalah sesuatu yang terjadi secara bersamaan
} 


\section{DAFTAR PUSTAKA}

[1] Ali, Muhammad. 2014. Metodologi dan Aplikasi Riset Pendidikan. Jakarta: Bumi Aksara.

[2] Agustino, Leo. 2016. Dasar- Dasar Kebijakan Publik. Bandung: Alfabeta.

[3] Boediono. 1999. Teori Pertumbuhan Ekonomi. Yogyakarta: BPFE.

[4] Budiati, Lilin. 2012. Good Governance Dalam Pengelolaan Lingkungan Hidup.Bogor: Ghalia Indonesia.

[5] Dunn, William N. 2003. Analisis Kebijakan Publik. Yogyakarta: Gadjah Mada University Press.

[6] Dwijowijoto, Riant Nugroho. Kebijakan Publik Formulasi, Implementasi danEvaluasi. Jakarta: PT. Elex Media Komputindo.

[7] Dwiyanto, Agus. 2006. Mewujudkan Good Governance Melayani Publik. Yogyakarta: Gadjah Mada University.

[8] Gaffar,Afan.2009.Politik Indonesia: Transisi Menuju Demokrasi. Yogyakarta: Pustaka Pelajar.

[9] Grindle, Merilee S. 1980. Politics and Policy Implementation in The Third World. New Jersey: Princeton University Press.

[10] Harun, Rasyid A. 1997. Manajemen Pelayanan Umum. Jakarta: Bumi Aksara.

[11] Hardiansyah. 2011. Kualitas Pelayanan Publik. Yogyakarta: Gava Media.

[12] HAW, Widjaja. 2004. Otonomi Desa.Jakarta: Rajawali Pers.

[13] Lukman, Sampara. 2000. Manajemen Kualitas Pelayanan. Jakarta: STIA LAN Press.Mulyadi.2007. Sistem Perencanaan dan Pengendalian Manajemen. Jakarta:Salemba Empat.

[14] Osborne, David \& Ted Gaebler. 1992. Reinventing Government: How The Entrepreneur Spirit is Transforming The Public Service, Terjemahan: Mewirausahakan Birokrasi Mentransformasikan Semangat Wirausaha ke Dalam Sektor Publik. Alih Bahasa Abdul Rosyid dan Ramelan. Jakarta: Pustaka Binaman Pressindo.

[15] Prasetyo, Bambang\& Lina Miftahul Jannah. 2005. Metode Penelitian.Kuantitatif.(Teori danAplikasi). Jakarta: PT Raja Grafindo Persada.

[16] Ratminto, Atik Septi Winarsih. 2007. Manajemen Pelayanan. Yogyakarta: Pustaka Belajar.

[17] Santoso, Singgih. 2012. Aplikasi Spss Pada Statistic Non Parametrik.Jakarta:Eles Media Komputindo. 
[18] Sedarmayanti. 2012. Good governance Dalam Rangka Otonomi Daerah.Bandung: Mandar Maju.

[19] Sinambela, Poltak Lijan., dkk. 2006. Reformasi Pelayanan Publik. Jakarta: Bumi Aksara.

[20] Singarimbun, Masri\& Sofyan Effendi. 1995.Metode Penelitian Survei.Jakarta:LP3S.

[21] Sugiyono. 2011. Metode Penelitian Kuantitatif Kualitatif Dan R\&D. Bandung:CV Alfabeta.

[22]Sugiarto., dkk. 2003. Teknik Sampling.Jakarta: PT Gramedia Pustaka Utama.

[23] Sugiyono, Statistika Untuk Penelitian, Alfabeta, Bandung, 2006, hlm. 237.

[24] Sujarweni, Wiratna V. 2014. SPSS Untuk Penelitian. Yogyakarta: Pustaka Baru Press.

[25] Thoha, Miftah. 2003. Birokrasi Pemerintah dan Kekuasaan di Indonesia. Yogyakarta: Thafa Media.

[26] Thoha, Miftah. 1995. Kepemimpinan dalam manajemen. Jakarta: Grafindo Persada.

[27] Tjiptono, Fandy. 2001. Manajemen Jasa edisi pertama. Yogyakarta: Andi Offset.

[28] Yamin, Sofyan \& Heri Kurniawan. 2014. SPSS Complete (Teknik Analsis Statistik Terlengkapdengan Software SPSS). Jakarta: Salemba Infotek. 